\title{
Contrasting Paths of Corporate Greening in Antipodean Agriculture: Organics and Green Production
}

Kristen Lyons, David Burch, Geoffrey Lawrence and Stewart Lockie

\section{Introduction}

Over the last few decades, and throughout the world, the corporate sector has sought to establish its environmental credentials by integrating environmental and social justice issues into its corporate policy agendas and practice. Such restructuring is particularly evident throughout agriculture and food systems, where food processors and retailers appear to have taken note of the lessons to be drawn from the growth of the organic food sector. The growth of organic production has led the corporate sector to address - in various ways and to different degrees - 'green' issues in shaping the trajectory of this development. For some corporate actors, the influence of 'green' concerns has been manifest in little more than expressions of concern and statements of intent, which are designed to disguise current unsustainable practices. For others, in contrast, it is reflected in the restructuring of food production systems in ways that support the production of organic food, the development of environmental codes of practices and other initiatives which represent a new policy direction.

In this chapter we analyse the different strategies of corporate greening which have emerged throughout the agri-food sector in the Antipodeans. In particular, we focus on two food companies - Uncle Tobys in Australia and Heinz Wattie in New Zealand and examine the specific greening practices of these firms, and the impacts of such practices for producers, consumers, and others engaged in food networks. An examination of these changes in the agri-food sector illustrates the various ways in which firms are responding to broader social and environmental challenges facing the agriculture and food industry. In particular, the analysis of these cases draws attention to the role of the production and processing sectors in Australia and New Zealand in developing strategies of corporate greening. This marks a significant contrast to strategies of greening occurring elsewhere, including the UK, where retailers have taken the lead in shaping the trajectory of systems of agriculture and food production. The findings from this chapter indicate that while food companies play a significant role in the Antipodean 
organic food sector - manifest in different ways across each of these locations - their entry to organics, to date, has not heralded a radical transformation of agricultural practices. While growth in the organic sector presents an opportunity to address those environmental and social problems that have emerged alongside the current farm crisis, the activities of food processing companies in the Antipodeans have gone only part way to address these challenges.

\section{Greening Agriculture and Food in Australia and New Zealand}

The organic food industry is currently the fastest growing food sector worldwide. With consumption growth rates calculated at twenty five percent annually, the industry is estimated to reach fifteen percent of total food consumption by 2005 (Kinnear, 1999). In Australia and New Zealand, the industry has undergone sustained growth over the last ten years, increasing in value from $\mathrm{A} \$ 28$ million in 1990 to $\mathrm{A} \$ 200$ million by 1999 in Australia, and from NZ\$1.1 million in 1988 to NZ\$60 million in 2000 in New Zealand (Kinnear, 1999; OPEG, 2000; Saunders et al., 1997). Alongside this increase in the value of industry output, the number of certified producers in Australia utilising organic methods has also increased substantially, from 491 producers in 1990 to an estimated 2000 by 1999 (Kinnear, 1999). Similarly, in New Zealand the number of organic farms has increased from 89 to an estimated 300 by 1997 (Saunders et al., 1997). As a part of this growth, the organic industries across each of these locations have become increasingly integrated with conventional food systems, evidenced by the increased interest in organics shown by food firms, government departments and research institutions.

This apparent greening of food and agriculture in Australia and New Zealand must be understood within the context of the social, economic and environmental crises that are currently being experienced by rural communities. The rapid growth in the organic sector - and the involvement of corporate actors in this sector - reflects, at least in part, a response to the problems emerging from these contemporary farm crises. Foremost amongst these problems include a decline in farm numbers; increasing poverty and indebtedness as only a small group of highly productive farms earn commercial rates of return on investment; poorer health indicators than for the wider population; and land 
and water degradation which impose substantial immediate costs while threatening longer-term productive viability (Lockie and Bourke, 2001). Constant shifts in demand raise new threats and opportunities. A joint report issued by Australia's National Farmers' Federation and the Australian Conservation Foundation in April 2000 estimated that environmental degradation associated with agriculture in Australia costs in excess of AUS\$2 billion annually and could rise to over AUS\$6 billion annually by 2020 (Madden et al., 2000). The amount of land affected by salinity alone could rise from 2.5 million to 15.5 million hectares unless action is taken. This is somewhat akin to an increase from an area the size of Belgium to an area the size of England and Wales. It is difficult to tell how much of New Zealand's agricultural lands are affected by erosion, salinity and other problems, as national data does not exist (Ministry for the Environment, 1997). Nevertheless, there is little reason to think that the situation is not similarly serious.

There is, in some respects, nothing new about environmental degradation, or attempts to address it, in Australian and New Zealand agriculture. Extensive soil erosion was a major political issue in both countries as far back as the 1890s and 1930s (Bradsen, 1988; Ministry for the Environment, 1997). By the 1970s over half of all agricultural lands in Australia required treatment for soil or vegetation degradation (DEHCD, 1978). There is also little new in the dominant approaches governments are taking to these issues, which focus on voluntary action on the part of landholders supported by research and education services provided by government (Bradsen, 1988; Ministry for the Environment, 1997). Even Australia’s much vaunted National Landcare Program - which is represented by government as a major investment in rural land degradation - is focussed towards encouraging voluntary action by providing limited financial support to community environmental groups (see Lockie and Vanclay, 1997). In the absence of more overt intervention, Landcare has been represented by some of its critics as a triumph of marketing over substance that does little to help cash-strapped farmers make anything more than incremental changes in farming practice (Lockie, 1997a, 1999). Despite this, over thirty percent of Australian farm businesses have at least one employee who is a Landcare group member (Mues et al., 1998) and the concept has spread to New Zealand, South Africa and elsewhere.

There are, however, at least two dimensions to the current phase of 'greening' 
that do appear novel. The first of these is the discourse of 'sustainable development' that circulates within contemporary agriculture, and the clear link that is made in these discourses between agricultural productivity and the conservation of natural resources. In contrast to the early days of soil and water conservation in Australia and New Zealand when strategies to protect resources were believed to have few immediate or obvious economic benefits, most contemporary strategies offer improved profitability in the short and long terms (Barr and Cary, 1992). 'Conservation farming', for example, also known as minimum, reduced or no-till farming, uses synthetic herbicides in preference to mechanical tillage as a means to reduce soil disturbance, compaction, and exposure while also reducing labour and increasing production (Barr and Cary, 1992). The second novel dimension is the development of discourses of food and environmental safety that stress, respectively, the impacts on human health and the impacts on other species and ecosystems of synthetic pesticides, fertilisers and veterinary drugs. More and more consumers, it seems, are not simply concerned about the fate of the countryside, they are worried about what the food they eat is doing to themselves.

At face value, the spectacular growth in the production and consumption of organic food in Australia and New Zealand, as in other parts of the world (notably Europe, the United States and Canada), supports the view that opposition to synthetic pesticides and fertilisers among consumers is growing. This trend challenges the dominant approach to soil and water conservation, that is, of replacing mechanical pest control with chemical controls. But it is also important to acknowledge a range of other factors and trends that mitigate against the shift towards organic production. First, the vast majority of farmers are sceptical of the ability of chemical-free farming systems to operate profitably and effectively, despite their own reservations about chemical use (Lockie, 1997b). Second, while high levels of financial support are made available to assist in the improvement of 'conventional' farming systems, there is little institutional support and research to assist farmers in making the move towards organics. In the face of constantly deteriorating terms of trade, most find farming a risky enough activity without abandoning their most accessible means of support (Lockie, 1997b). Third, there a number of alternative means to reduce chemical residues or demonstrate product safety which stop short of full conversion to organic production. For example, integrated pest 
management (IPM) strategies reduce chemical use through more careful monitoring of pest populations and the use of both chemical and alternative means of control, while quality assurance (QA) systems such as the International Organization for Standardisation (ISO) allow tracking of produce from farm to consumer and provide guarantees that farmers have followed all the necessary procedures to reduce the risk of residues. Increasingly, large retailers and processors in Australia require farmers to adopt certified QA procedures (Lockie, 1998). Fourth, there is some evidence to suggest that many consumers of organic foods do so principally out of concern for the effects of chemical residues or genetically-modified organisms on their own health and well-being, rather than a concern for the environment (Lyons, 2000, 2001). Unless these consumers can be convinced either that looking after the environment and looking after themselves are essentially one and the same thing, or that organic certification is substantially more trustworthy than the alternatives, there is every possibility that they may favour those foods produced via certified IPM or QA processes - particularly when cheaper - over organics.

It should be no great surprise that not only is the greening of agriculture a complex and contested process, but that there is not always a direct relationship between the greening of food production and the greening of food consumption. Programs like Australia's National Landcare Program and technologies like 'conservation farming' demonstrate how successfully discourses of sustainability have been incorporated within conventional agriculture while displacing concerns about chemical use to the realm of food safety and quality assurance. By promoting a discursive link between environmental and personal health - as illustrated in varying degrees by the activities of Uncle Tobys and Heinz Wattie, as discussed below - the organic industry seeks to challenge this displacement. However, it is arguable that the ways in which these discourses are taken up by corporate capital in their own greening strategies depend upon, and are critical to, perceptions of a separation between environmental sustainability and resource use on the one hand, and food safety and the use of agri-chemicals on the other. This is clear when we examine the pathways towards corporate greening in Australia and New Zealand, and compare these with that in Europe. 


\section{Corporate Capital and Greening}

The involvement of corporate capital in the agri-food sector of most industrialised countries, including Australia and New Zealand, has been an important impetus in expanding the size of the organic industry. These firms have engaged in discourses around the notion of 'clean and green' production - including organics - with the aim of addressing the two issues discussed above, that concerning sustainable development and that relating to food safety (Burch et al., 2001). Many corporations point to the adoption of concepts such as the 'triple bottom line', involving not just profitability as the main determinant of corporate effectiveness, but also embracing environmental responsibility and social equity, as evidence that they are committed to the adoption of sustainable production practices (Elkington, 1998). In this regard, the corporate sector has argued that it too, has an interest in sustainable development, in part because consumer groups expect corporations to behave responsibly, and in part because companies are able to make savings by minimizing waste and better managing their use of scarce resources.

Such claims are not uncontested, and many critics have argued that this projection of 'corporate greening' is merely a public relations exercise - or a 'greenwash' - which is aimed not at making substantial changes to current practice but, rather, is designed to improve a company's image at a time when many consumers and citizens are becoming increasingly concerned about large-scale environmental degradation (Beder, 1997; Greer and Bruno, 1996; Welford, 1997). From this perspective, capitalist enterprises are unable to change their behaviour because their main priority is still the maximisation of profits for the benefit of their shareholders.

In terms of this debate, we take the view that it is not possible to generalise across all instances on the basis of a priori assumptions about the capacity of capitalist institutions to embrace the principles of sustainable development or not. The situation may well vary from company to company, from sector to sector and from country to country, and each case must be decided on its merits (Lawrence, 1999). In Australia and New Zealand, many food companies now produce a range of organic products, including breakfast cereals, frozen vegetables, baby foods, honey, pasta and soy products, which are distributed throughout both the domestic and international markets (Burch et al., 2001; Lyons, 1999, 2001). In Australia, Uncle Tobys, Berrivale and Sandhurst produce a 
range of organic breakfast cereals and fruit beverages, while in New Zealand, Heinz Wattie's Australasia, Talley's Frozen Foods and McCains Foods process frozen vegetables, Only Organic Baby Food Ltd distributes a range of baby foods, and New Zealand Biograins retails cereals and oilseeds (see Lyons, 1999, 2001; Monk, 1998). An examination of a selected food firm across each of these locations provides a context to assess the specificities associated with the involvement of two food processing companies in organic agriculture, and the degree to which this involvement represents a genuine shift to 'green production'.

\section{The Entry of Corporate Capital to Organic Agriculture}

A detailed analysis of case material avoids the problem of over-generalising about the capacity of the corporate sector to respond to consumer concerns about environmental degradation and/or food safety. By focusing on the specificities of each case, the case study approach allows claims to corporate greening be decided on their merits. To this end, this paper will now overview the activities of Uncle Tobys in Australia, and Heinz Wattie in New Zealand, prior to assessing the implications of their involvement in organic production for Antipodean organic food and agriculture, and our understandings of green production more generally.

\subsection{Uncle Tobys}

Uncle Tobys is the brand name of a range of cereal products manufactured by Australia and New Zealand's largest food company, Goodman Fielder. This diversified company produces a wide range of food lines, marketed under a variety of brand names; edible oils (Meadow Lea, Praise and Crisco), milling and baking (Wonder White and Nature's Fresh), poultry (Steggles), pastry (Pampas) and gelatine. Until 1999, Goodman Fielder also owned a poultry processing company called Steggles, and along with its baking operations, supplied leading food chains such as McDonald's with ingredients, including chicken McNuggets, buns and crumpets. Goodman Fielder dominates a range of sectors in the Australian food industry, although with the sale of Steggles in 1999, and the acquisition of Defiance baking operations and New Zealand's biggest baker, Ernest Adams, it has come to concentrate on a few core activities in milling and baking. In the 
period 1999-2000, the company made a profit of $\$ 130.9$ million (Goodman Fielder, 2000). The company produces only one line of organic products, the Uncle Tobys brand of breakfast cereal called 'Organic Vita Brits'.

Uncle Tobys has been producing a rectangular shaped breakfast cereal biscuit called 'Vita Brits', made from conventionally-produced raw materials, since 1935. In 1991 the conventional product was replaced by 'Organic Vita Brits'. The release of this organic breakfast cereal was Uncle Tobys first overt 'green production' strategy, and signalled a substantive shift from their reliance on predominantly conventional food production systems for the supply of inputs for their broader range of processed foods. However, in 1997, the company withdrew from the organics market. This withdrawal was related to the increasing cost of sourcing organic wheat and what Uncle Tobys identified as limited consumer interest in 'Organic Vita Brits'. Uncle Tobys did, however, continue to produce 'Vita Brits' using conventionally-produced inputs. In 1999, the company re-introduced the organic line of 'Vita Brits', so that both product lines are now marketed. 'Organic Vita Brits' currently retail at a small premium (less than five per cent) above the price of the conventional counterpart. Despite this product differentiation, Uncle Tobys markets both their organic and conventional products as healthy and nutritious (Lyons, 1999).

Uncle Tobys has employed various additional marketing strategies to promote its organic product, and to define aspects of 'green production' systems. Uncle Tobys began to source organic wheat in 1990 for processing their breakfast cereal for market release the following year. To source organic wheat, Uncle Tobys established verbal contract relationships with producers located in regions that were in close proximity to their processing plants in Victoria and Queensland. With their subsequent re-entry into the organic market in 1999, Uncle Tobys centralised the production of 'Organic Vita Brits' to the Victorian plant, and thus dissolved agreements with producers previously supplying the Queensland operation. All producers supplying Uncle Tobys have been involved in the organic industry for some years, and are certified 'Level A' by the National Association of Sustainable Agriculture Australia (NASAA) - one of the largest organic certification organisations in Australia. Uncle Tobys does not encourage conventional wheat producers to convert to organic practices, preferring to source 
organic wheat from established organic farms. In addition, Uncle Tobys processing plants are also certified by NASAA. 'Organic Vita Brits' provides a relatively simple product for Uncle Tobys to produce organically, as they only require one organic input - wheat. In contrast, most Uncle Tobys products require a range of inputs, including fruits, nuts and other grains, and as such, would be more difficult to produce organically. Consequently, Uncle Tobys remains uninterested in producing any other organic food. Goodman Fielder has to date taken no steps to convert other cereal products - marketed either under Uncle Tobys or its other cereal brand, Bluebird Foods - to organic production. To date, all 'Organic Vita Brits' have retailed on the domestic markets, except small quantities exported to New Zealand (Lyons, 1999).

\subsection{Heinz Wattie}

Heinz Wattie Australasia is one of the world's leading food processors, and is most well known for brands including, Heinz, Watties and Weight Watchers, as well as Ore-Ida, The Budget Gourmet, and StarKist. Heinz Wattie Australasia was formed in 1998 after the merger of Heinz Australia and Heinz Wattie. Heinz Wattie first entered into 'green production' in 1991 by way of processing frozen organic peas, carrots, sweet corn and potatoes in New Zealand. Producers currently contracted to supply Heinz Wattie with organic vegetables are centrally located around a number of processing plants, with the most concentrated area under organic pea production at Canterbury, in the South Island of New Zealand. All producers that supply Heinz Wattie with organic produce are required to obtain organic certification from Bio-Gro New Zealand - the leading certification agency in New Zealand - and processing plants are also certified by BioGro. As part of a strategy to ensure a continual supply of vegetables from farms in close proximity to processing facilities, Heinz Wattie developed a Grow Organic with Watties program in 1990, which aimed to encourage conventional producers to convert to organic production, and to support them during this transition process. This program provides information on Bio-Gro certification standards, as well as advisory services from Heinz Wattie field officers. The development of this program to encourage and support producers throughout conversion to organic farming practices contrasts with the case of Uncle Tobys, who provided little or no support services to producers, but rather preferred 
to source inputs from already established organic farms. The success of the Heinz Wattie program for the New Zealand organic industry is reflected in the area converted to organic production, which in 1998 represented fifteen per cent of the total land contracted by Heinz Wattie nationwide (Anon, 1998). Heinz Wattie currently contracts with 50 certified organic producers, who farm an area of 2500 hectares (Heinz Wattie, 2000). Heinz Wattie organic frozen vegetables are retailed throughout Japan, Europe, the United States, South Africa, Australia and New Zealand.

\section{Constructing 'Organics’: Food Products and Corporate Identity}

The entry of Uncle Tobys and Heinz Wattie to the organic industry represents, at least in part, a response to the various pressures exerted by consumers and others in the food production sector. Not least amongst these is the pressure to 'green production' methods, so as to address - or at least make some attempts to address - those social and environmental problems facing rural communities and their environments, as well as attending to some of the concerns expressed by consumers about food safety. As an outcome of such dynamics, a number of changes are evident throughout Antipodean corporate food production sectors (in contrast to the retail sector evidenced in the UK).

To begin, corporate support for organic production systems - as evidenced by Heinz Wattie and Uncle Tobys - represent a significant departure from dominant cultural values and beliefs about farming, including those that prioritize conventional inputintensive farming methods. As discussed earlier, the priority still accorded to conventional farming methods derives from the belief that such methods can offer some solutions to agri-environmental problems. The evidence for this is to be found in the extensive government and industry support for chemical-intensive farming methods in Australia and New Zealand, while organic methods have been overlooked, and often criticised and ridiculed (Lyons, 2001). Corporate participation in the organic industry thus appears to represent a substantial departure from traditional techniques of food production. The participation by corporate actors in the organic industry has been manifest in material and symbolic transformations of the practices of these firms. That is, corporate food firms have altered aspects of both their food production systems, as well as the meanings of such systems and the foods they produce. It is important to note at this 
point that an array of actors - including farmers, certification agencies, consumers and others - play a key part in determining the material and symbolic character of organic food and agriculture. Each of these actors is also active in constructing meanings surrounding organic food and agriculture (see Lyons, 2000). This chapter, however, focuses specifically on the symbolic meanings which corporate actors associate with organic food in order to examine the various strategies companies engage in to construct meanings of environmentally-related symbols - including organics - and in turn, the ways in which they have associated such symbols with their products. Uncle Tobys and Heinz Wattie have, to varying degrees, embodied these meanings as part of a corporate philosophy.

Between 1991 and 1997, and 1999 to the present - Uncle Tobys undertook two broad marketing strategies that signified attempts to associate environmentally-related symbols with their product. These strategies signified an attempt to shape understandings of organics and 'green production' more generally. The first of these strategies - manifest through packaging, advertising through television and print media and promotional material - involved constructing a connection between the self, the environment, and the consumption of their product (Lyons, 1999, 2000). As part of this process, Uncle Tobys utilised environmental signifiers to re-shape both their product, as well as that of their corporate image. In order to illustrate this theme, packaging and promotional material includes various signifiers, such as the NASAA certification logo, which ensures all ingredients are produced according to the strict guidelines stipulated by this organic certification organisation. Additionally, boxes of 'Organic Vita Brits' utilised the slogan Organic Food: Healthy For You, Healthy For The Environment, and listed the benefits of organic farming practices for the environment. An important additional greening strategy Uncle Tobys undertook was the sponsorship of Landcare Australia Ltd, entitling them to use the Landcare logo on boxes of 'Organic Vita Brits'. The 'caring hands' that signifies Landcare has been endorsed widely within the corporate world as an indicator of environmental concern, and has consequently been adopted by many corporations including Monsanto, BP and BHP (Lockie, 1997a). Thus, this signifier enabled Uncle Tobys to associate both their product, and concomitantly their corporate image, with a healthy environment. This meaning of organics concurred with those meanings 
associated with other 'green production' labels applied to Antipodean agriculture including the Landcare program, IPM and conservation farming - which also promoted environmental integrity and environmental sustainability. An important point to note here is that the adoption of an organic label required Uncle Tobys to alter their production system - that is, to source organic wheat and process their product following organic certification standards. Support for the Landcare program however, was in the form of a financial contribution, and did not require any alterations to production methods. Green production in this context thus represented a symbolic only, rather than a material, shift in corporate practices.

A second and closely linked discourse utilised by Uncle Tobys sought to associate organic food, and concomitantly their corporate image and green production more generally, with health. Slogans such as Organic Food: Healthy For You, Healthy For The Environment, suggested not only a commitment to a healthy environment, but also to healthy bodies. These symbolic constructions indicated the consumption of 'Organic Vita Brits' contributed to a healthy diet and good health. Well known Australian beach and surf lifesavers, signifying safety and health (see Fiske et al., 1987), are also employed to promote 'Organic Vita Brits', further reinforcing this linkage. With the re-release of their organic product in 1999, Uncle Tobys further expanded the connection between healthy bodies, 'Organic Vita Brits', and their corporate image. In particular, Uncle Tobys was an Official Sponsor of the Sydney 2000 Olympic Games, and its owner, Goodman Fielder, committed over 1000 tonnes of food to athletes, officials and guests throughout the Olympics. By these actions, Uncle Tobys and its parent company have assisted in attaching meanings associated with health and fitness to both their products, as well as the companies themselves. The use of healthy bodies - including that of high profile Australian swimmer Lisa Curry-Kenny - to promote environmental initiatives such as Landcare, and later Coastcare, further strengthened this relationship, as well as connecting a healthy environment with personal health (Lyons, 1999).

Heinz Wattie, in contrast, engage to a much lesser extent than Uncle Tobys with these signifiers. Heinz Wattie does, however, indicate its products are certified 'organic', thus appealing to similar consumer concerns. To date, demand for their products has outstripped supply - particularly throughout Japan, the West Coast of America and 
Europe - and while it is clear that such foods are highly sought after, it is less well understood why consumers demand these foods. In addition to this promotion of their product, Heinz Wattie have also indicated a broader corporate commitment to environmental concerns, and in particular, have adopted a corporate environmental philosophy which is monitored by their environmental program called 'Environmental Honesty' (Anon, 1996). The adoption of this program illustrates Heinz Wattie's attempt to position itself as an environmentally responsible company. The corporate greening strategies undertaken by Heinz Wattie illustrate a somewhat more holistic approach to greening production than those undertaken by Uncle Tobys. While both companies sourced organic inputs, Heinz Wattie have developed an Environmental Program to address the more general environmental problems related to the company.

These case-studies of Uncle Tobys and Heinz Wattie show how each of these firms have actively sought, firstly, to shape understandings of 'green production', and secondly, to attach these meanings to their organic products. Uncle Tobys' promotion of its organic product illustrates the importance of both the maintenance of environmental integrity during food production, alongside the health aspects of foodstuffs themselves. This firm's endorsement of Landcare and Coastcare programs reiterates the importance which Uncle Tobys place on the environmental integrity of production. However, alongside Uncle Tobys re-entry to the organic market in 1999, their marketing more closely focused on those meanings associated with the health of organic foods (Lyons, 1999). While the company initially sought to attach meanings associated with both the environment and health to organic foods, recent marketing has promoted health and fitness.

However, before we attempt to evaluate the experiences of these companies, there is one important observation that needs to be considered. There is a significant difference that emerges when we analyse corporate greening in Australia and New Zealand, and compare it with experiences elsewhere, particularly Europe. This difference relates to the sources of the pressure for companies to adopt sustainable practices - that is, in who takes the lead in shaping changes in the food production sector. This is significant because it may allow us some insight into the nature and form of corporate greening strategies, and whether or not any particular policy or action involves a meaningful 
commitment to sustainability, or whether it is a 'greenwash' (or even something else).

\section{Retail Sector and Greening}

In terms of 'green production', the experiences of the agri-food sector in the UK and Europe are very different from those emerging in Australia or New Zealand. While organic farming is expanding everywhere at a rapid rate, in the case of the UK much of the stimulus for this has come from the retail sector, and the supermarket chains in particular, which have placed a good deal of pressure on agri-food processors and producers to introduce environmentally sustainable practices that deliver safe foods and reduce the environmental impacts of farming. Thus, UK-based retail chains such as Sainsbury, Iceland and Tesco, have well-developed environmental management policies which go beyond a commitment to the marketing of organic produce. In the case of Sainsbury, for example, such management policies extend over the entire range of their operations, and the company produces an annual environment report which not only documents past progress but also sets new targets for the year ahead (Sainsbury, 2000).

In the area of product sourcing, for example, Sainsbury impinges directly on the agri-food production system, imposing what it claims are environmentally responsible policies through the standards and requirements it stipulates to farmers and food processors who supply the company's own brand products. Sainsbury began to do this in 1991, when it introduced its integrated crop management (ICM) protocols for all UK fresh and frozen fruit and vegetables. The ICM protocol is a mutually agreed program which specifies best practice for crop production and which works to achieve the reduction of agri-chemical inputs, and the company has plans to ensure independent verification of similar standards in the case of overseas suppliers. In addition, in 2000, the company was trialing an environmental management system which would apply to the more than 1200 own-brand suppliers in 2001. Sainsbury also encourages wildlife conservation by sourcing from suppliers who have implemented Farm Biodiversity Action Plans (FBAP), and in 2000, also began to sell seafood sourced from fisheries which have been certified as sustainable by the Marine Stewardship Council (MSC). Allin-all, only 251 suppliers, out of a total of 3000, were not producing under ICM, FBAP or similar guidelines. These initiatives are separate from the company's policy of marketing 
fully-certified organic produce, which it first started to sell in 1986 (Burch et al., 2001).

It may be argued that such action is a 'greenwash' marketing tool, and is simply designed to generate a more favourable image for the company in the minds of the public. However, as has been argued elsewhere (Burch et al., 2001), in the case of Sainsbury, there appears to be a significant difference in corporate outlook which results in changes in behaviour which are meaningful, but limited by external constraints - a 'partial greening' in other words. But whatever the case, the evidence suggests that in Europe, the retail sector has taken the lead in shaping policy and behaviour at the farm level. By way of contrast, in Australia and New Zealand, the retail sector has not behaved in the same way, and there is little evidence of any broad-based or sustainable push to encourage suppliers to meet 'clean and green' standards in their management of the natural resource base. Of course, the supermarkets do insist on quality standards relating to consumption, and there has been some moderate interest on the part of supermarkets in selling a limited range of organic products already being produced (Monk, 1998). But even where retailers are marketing their own-brand supermarket labels, a situation which normally gives them a good deal of control over downstream production and processing, there has been no concerted attempt to impose environmental management standards of production on suppliers, in the ways that Sainsbury and other retailers have done in the UK.

Instead, the impetus to what is claimed to be 'green' production in Australia and New Zealand has come from the production sectors themselves, and in terms of corporate greening, from companies such as Heinz Wattie and Uncle Tobys. Why is there this difference and is it of any importance? There does seem to us to be some significance in the fact that the impulse to green production comes from different sectors. While it is true that the retail sector is probably more closely attuned to expressions of consumer preferences than the production sectors, supermarket chains in the Antipodes have been spared some of the numerous and extreme food scares that have been so prevalent in Europe and elsewhere. Consumers in Australia and New Zealand appear to be more likely to believe the message put out by government and industry, that food supplies are already 'clean and green' and safe to eat (Alexander and Fry, 1994). More important than that though, are the implications of the point made earlier in this paper. Government 
initiatives like Landcare and the greening strategies adopted by the corporate sector, have succeeded in incorporating a discourse of sustainability into conventional agriculture while disassociating this from concerns about food safety. In other words, in the Antipodes, the link between environmental sustainability and resource use, and food safety and the adoption of conventional farming methods - is not well articulated.

In Europe, by way of contrast, many recent food scares have been seen to be directly related to the adoption of intensive methods of production, and there is a clear link established between the viability of the natural resource base and the quality and safety of products. The retail sector in Europe is usually the first point of contact for expressions of consumer concern about food safety, and while the production sectors obviously experience great disruption and loss of income when major food scares such as 'Mad Cow Disease' emerge, the supermarket chains, operating in a highly competitive environment, clearly see some benefit in moving downstream in order to impose standards on both the quality of food and the sustainability of the production base. In a situation in which the standard of food is so closely related to the sustainability of the resource base - in terms of chemical residues and animal health, etc. - there are clear incentives for retailers to get involved in the food production system. This is more so the case where major retailers such as Sainsbury depend upon the sale of high quality 'own brands' for the larger part of their total turnover. In this context retailers, not producers, become the guarantors of quality, and it is not surprising to see the retail chains moving downstream in order to ensure the foods they market under their own labels are produced to the highest standards and in ways which are both sustainable and safe.

As a consequence of these distinctions, the main impetus to 'green production' in Europe comes from the retail sector, while in Australia and New Zealand, it comes from the production sectors, which have subscribed to organic production methods largely as an aid to marketing rather than a commitment to sustainable production methods. But there are other consequences that emerge from the distinctions outlined above, which enable us to evaluate the extent of the commitment of companies like Uncle Tobys and Heinz Wattie to meaningful change.

\section{First and Second Phase Greening}


Worldwide, environmental and health discourses are increasingly influencing the shape of food production and consumption. Responding to changes in community perceptions towards - and attitudes about - foods the industry has begun to employ 'green' signifiers aimed at convincing consumers not only of the healthy nature of the product they are consuming, but also of the environmental credentials of the firms involved in food production. Whether this is simply 'greenwashing' (see Beder, 1997) is a matter of some importance. Burch et al. (2001) argue that the organic sourcing policies of Uncle Tobys and Heinz Wattie herald the move toward corporate greening, but only to a limited degree. Although these companies are adhering to certified standards in the production of organic foods, there are problems with other aspects of the total production and distribution system which raise serious questions about the sustainability of the company's activities. For example, the frozen vegetables are packaged in resourceintensive and non-renewable plastic bags, in the same way as the conventionallyproduced lines. Moreover, unlike organic produce - which is grown to be sold in local markets - these corporate organic lines are mostly exported and therefore have to travel thousands of 'food miles' before they reach the consumer. There is then, a considerable amount of non-renewable energy used in transporting and distributing the 'organic' product. Uncle Tobys, in particular, has illustrated no commitment to expanding the organic industry, or increasing their range of organic products. Burch et al. (2001) conclude that what we are witnessing in the case of both Uncle Tobys and Heinz Wattie is first phase - or partial - greening. Second phase - or full - greening might be deemed to be occurring when the agri-food companies subject the total process of production, processing and distribution to some kind of environmental audit. This might occur when they 'reach forward' in the off-farm aspects of processing and delivery, ensuring that food processing is in accordance with consumer demands for correct labelling, packaging is made from recyclable products, and that high energy-using processes for moving foods are replaced with more energy efficient forms of transport. Alternatively, second phase greening might be deemed to occur when the supermarkets or fast food companies selling a product 'reach backward' into the chain of production to ensure that soil loss is minimised, animal welfare is enhanced, and chemicals are either banned or their use is reduced. 
On the basis of this formulation, it can be argued that there is evidence of second phase greening occurring in Britian and other European nations. In the UK, companies such as Sainsbury and Tesco appear to be accepting responsibility for the delivery of environmentally-friendly products to increasingly-discerning consumers. In doing so, retail companies are not only meeting consumer demands, but are also conforming to the tough regulatory frameworks that have emerged in an era of BSE and foot and mouth scares (Johnson, 1998). However, the activities of companies such as Uncle Tobys and Heinz Wattie suggest that what is occurring in Australia and New Zealand is first phase greening, and that the corporate sector there has little, if any, commitment to wider questions of sustainability.

The extent to which the move to organics is bound up with wider concerns about sustainable development is another point of interest in this discussion. Leaving aside the definitional difficulties associated with sustainability (see Drummond and Marsden, 1999; Paehlke, 1999) it can be stated unambiguously that governments in Australia and New Zealand are committed to the principles of sustainability. But there is also growing evidence that governments are relying on voluntary and 'self-help' means to bring about change. Landcare, highlighted earlier in the chapter, is one example. Another is the development of 'self help' models, where limited funding is devolved to local catchment groups for expenditure on 'on ground' works, such as water and soil catchment management (see AFFA, 2000).

Apart from displaying the symbol of Landcare on corporate publicity materials as a sign of strong commitment to the ideals of sustainability - few corporations have provided large-scale funding to communities to encourage a 'greener' future. Yet, according to Barr and Cary (2000) it is unlikely that 'community action' by itself will generate the needed changes in rural areas. These authors believe there is only a certain extent to which the 'stewardship ethic' can be harnessed to drive the profound changes necessary in thought and behaviour. Barr and Cary (2000) also highlight the apparent 'truism' of Australian agriculture - that there is a strong tendency for farmers to perceive environmental problems to be greater on neighbouring properties than on their own (many thereby having a 'justification' for inaction). Finally, the authors remind us that, as a voluntary activity, Landcare is unlikely to inspire more people to join the movement 
(the one third of farmers currently engaged is unlikely to increase). A more important criticism is that there is no evidence that the Landcare approach leads to fundamental alteration to productionist agriculture (see Gray and Lawrence, 2001; Lockie, 1999). Under present landowning laws, many producers believe they have rights to do as they wish with their 'own' resources - even where those resources are rivers, streams and biodiversity (Reeve, 2001). Despite the extraordinary amount of voluntary activities that have been undertaken by members of Landcare groups to address environmental degradation - in particular tree planting, fencing, pasture establishment and farm planning (Curtis and De Lacy, 1997) - a number of factors limit the impact of cooperative community action. These include the contradictions between such action and the highly individualised understandings of property rights that dominate rural Australia (Reeve, 2001); the pressures placed on producers by tightening terms of trade to lift profitability by intensifying production (Lockie, 1999); and the huge amount of government and corporate research and education devoted to supporting the high input agenda (Lockie, 2001). Thus, while it appears that Landcare groups have made significant inroads in dealing with some of the more pressing environmental externalities generated by current agricultural practices, they have done so in a way that will support the continued intensification of input use that many believe will lead to accelerating environmental problems (Lockie, 1999).

Will a 'sustainable organics' agenda be introduced in the Antipodes? As Lyons (1998) has reported, many new, corporate-linked, organic growers see themselves as oldfashioned organic growers, some of whom are quite happy to be labelled as 'greenies'. What we might suggest is happening, is the emergence of a division among organic producers based on particular conceptions of the 'meaning' of organic and its place in a more sustainable agriculture (Lyons and Lawrence, 2001). The more that organics becomes a corporate-commercial reality, the less inclined will the 'new' producers entering the industry be to accept the old - and strict - parameters of production. As suggested elsewhere, organic growers who cherish the 'anti' global/corporate world have good reason to be concerned that a corporate-linked organics is a trick to convince consumers that they are receiving 'clean and green' foods. This is despite the fact that the downstream system remains largely untouched, and the use of energy and production of 
wastes is no different from that of any other commodity within industrial agriculture (Burch et al., 2001).

Many of the new organic producers are drawn to the industry for its profit-making potential. While this is a legitimate motivation within a system of capitalist production and exchange, it is not one that shares the discourses, images, ideas and philosophies that accord with those producers who believe organics is the sustainable future for Antipodean agriculture.

\section{Conclusion}

This paper has illustrated the various strategies of green production undertaken between corporate actors, and across various agri-food sectors. It is apparent that Uncle Tobys and Heinz Wattie have engaged with organic production in diverse ways, and these have resulted in varying degrees of success in 'greening' their production systems. Furthermore, the actions of each of these companies located in the Antipodeans diverge from those undertaken in other parts of the world - notably Europe, where impetus for green production has arisen largely from the retail sector. The drivers for such change in turn impact on the adoption of green strategies and their implementation. For example, the greening that has occurred throughout the European retail sector has resulted in alterations to production, processing, packaging and transport of food products. The retail sector has thus linked the various elements comprising the food system, and has addressed concerns at each of these points as part of their greening strategy. In contrast, Uncle Tobys and Heinz Wattie have altered specific activities situated at a discrete location in the food system. These activities have included sourcing organic inputs, as well as sponsorship of the Landcare and Coastcare programs in Australia, and the development of an Environmental Honesty program in New Zealand. While the activities of these firms represent an important part of the shift to greener production, they overlook the impacts that derive from other points in the food system. In this way, the practices of Heinz Wattie and Uncle Tobys represent a somewhat limited option in altering food production in fundamental ways required to achieve a socially and environmentally sustainable food system.

Despite the 'partial' greening of food production facilitated by the entry of these 
corporate actors into organics, their involvement has been integral to the recent rapid growth of the organic food industry. Throughout the history of Antipodean agriculture (and that occurring elsewhere), chemical intensive systems of food provision have been normalised. This is evidenced most specifically throughout the policies and research agendas of government departments. Corporate support for organics has, therefore, challenged some broadly held assumptions that have historically marginalised and inhibited the growth of the organic industry. Corporate actors have thus been critical to the rapid growth of the organic sector in Australia and New Zealand. The long-term implications of this involvement for the industry remain to be seen. To date it is evident that a bifurcation has developed between growers who support the formalisation of the organic industry - including the entry of corporate actors and government departments and those who oppose such changes, but rather value organic systems for their supply of non-processed foods to local markets.

The cases of Uncle Tobys and Heinz Wattie also illustrate those meanings of organics constructed around their organic products. Broadly speaking, each of these companies associated two discourses with their organic product - that of environmental sustainability, and food safety and health. The case of Uncle Tobys revealed the privileging of health amongst these meanings as part of the marketing of 'Organic Vita Brits'. The failure to connect (and to maintain a connection) between each of these meanings further magnified divisions with the organic industry. While these actors themselves may benefit by engaging with aspects of 'green production' - including sourcing organic inputs - such activities have led to a range of impacts for the organic industry.

\section{References}

Agriculture, Fisheries and Forestry - Australia (AFFA)(2000) Steering Committee Report to Australian Governments on the Public Response to 'Managing Natural Resources in Rural Australia for a Sustainable Future...'. Canberra: AFFA.

Alexander, H. and R. Fry (1994) 'Showing the World the Way: The World Market for Clean and Green Products’, Agricultural Science (January): 39-44. 
Anonymous (1996) 'Watties Frozen Foods - Certified Organic Frozen Vegetables', Food Australia 38 (8): 352-353.

Anonymous (1998) ‘Organic Land Grows’, Grow Organic (March): 1.

Barr, N. and J. Cary (1992) Greening a Brown Land: the Australian Search for Sustainable Land Use. Melbourne: Macmillan.

Barr, N. and J. Cary (2000) Influencing Improved Natural Resource Management on Farms: a Guide to Understanding Factors Influencing the Adoption of Sustainable Resource Practices. Canberra: Bureau of Rural Sciences.

Becker, E. and T. Jahn (eds) (1999) Sustainability and the Social Sciences. Paris: UNESCO.

Beder, S. (1997) Global Spin: the Corporate Assault on Environmentalism. Melbourne: Scribe Publications.

Bradsen, J. (1988) Soil Conservation Legislation in Australia: Report to the National Soil Conservation Program. Adelaide: University of Adelaide.

Burch, D., K. Lyons and G. Lawrence (2001) 'What Do We Mean by 'Green'? Consumers, Agriculture and the Food Industry'. in S. Lockie and B. Pritchard (eds) Consuming Foods, Sustaining Environments, pp. 33-46. Brisbane: Academic Press.

Campbell, H., J. Fairweather and D. Steven (1997) Recent Developments in Organic Food Production in New Zealand: Part 2, Kiwifruit in the Bay of Plenty. Dunedine: University of Otago.

Curtis, A. and T. De Lacy (1997) 'Examining the Assumptions Underlying Landcare', in S. Lockie and F. Vanclay (eds) Critical Landcare, pp. 185-200. Wagga Wagga: Centre for Rural Social Research Key Papers No. 5, Charles Sturt University.

Department of Environment, Housing and Community Development (1978) A Basis for Soil Conservation Policy in Australia: Commonwealth and State Government Collaborative Soil Conservation Study, 1975-77. Canberra: AGPS Press.

Drummond, I. and T. Marsden (1999) The Condition of Sustainability. London: Routledge.

Elkington, J. (1998) Cannibals with Forks: The Triple Bottom Line of $21^{\text {st }}$ Century Business. Gabriola Island, BC: New Society Publishers Ltd.

Fiske, J., B. Hodge and G. Turner (1987) Myths of Oz. NSW: Allen and Unwin. 
Goodman Fielder (2000) Goodman Fielder Annual Report. Sydney: Goodman Fielder Limited.

Gray, I. and G. Lawrence (2001) A Future for Regional Australia: Escaping Global Misfortune. Cambridge: Cambridge University Press.

Greer, J. and K. Bruno (1996) Greenwash: The Reality Behind Corporate Environmentalism. Penang: Third World Network.

Heinz Wattie (2000) Heinz Wattie's Australasia. http://www.organicsnewzealand.org.nz/members/heinzwattie.htm

Johnson, D. (1998) 'Green Businesses: Perspectives from Management and Business Ethics', Society and Natural Resources 11: 259-266.

Kinnear, S. (1999) 'Overview of the Organic Industry in Australia', paper presented at Farming For the Future. Organic Produce for the 21st Century, Mackay, Queensland (22-23 September).

Lawrence, G. (1999) 'Agri-food Restructuring: a Synthesis of Recent Australian Research', Rural Sociology 64 (2): 186-202.

Lockie, S. (1997a) 'Beyond a 'Good Thing': Political Interests and the Meaning of Landcare', in S. Lockie and F. Vanclay (eds) Critical Landcare, pp. 29-44. Wagga Wagga: Centre for Rural Social Research Key Papers No. 5, Charles Sturt University - Riverina.

Lockie, S. (1997b) 'Chemical Risk and the Self-Calculating Farmer: Diffuse Chemical Use in Australian Broadacre Farming Systems’, Current Sociology 45(3): 81-97.

Lockie, S. (1998) 'Environmental and Social Risks, and the Construction of 'BestPractice' in Australian Agriculture', Agriculture and Human Values 15(3): 243252.

Lockie, S. (1999) 'Community Movements and Corporate Images: "Landcare” in Australia', Rural Sociology 64(2): 219-233.

Lockie, S. (2001) 'Name Your Poison': The Discursive Construction of Chemical-Use as Everyday Farming Practice'. In S. Lockie and B. Pritchard (eds) Consuming Foods, Sustaining Environments, pp. 140-158. Brisbane: Academic Press.

Lockie, S. and L. Bourke (eds) (2001) Rurality Bites: The Social and Environmental Transformation of Rural and Regional Australia. Sydney: Pluto Press. 
Lockie, S., K. Lyons and G. Lawrence (2000) 'Constructing “Green” Foods: Corporate Capital, Risk and Organic Farming in Australia and New Zealand', Agriculture and Human Values 17(4): 315-322.

Lockie, S. and F. Vanclay (1997) Critical Landcare. Wagga Wagga: Centre for Rural Social Research Key Papers No. 5, Charles Sturt University - Riverina.

Lyons, K. (1998) 'Understanding Organic Farm Practice: Contributions from Ecofeminism', in D. Burch, G. Lawrence, R. Rickson and J. Goss (eds) Australasian Food and Farming in a Globalized Economy: Recent Developments and Future Prospects, 57-68. Melbourne: Monash Publications in Geography No. 50.

Lyons, K. (1999) 'Corporate Environmentalism and Organic Agriculture in Australia: The Case of Uncle Tobys', Rural Sociology 64 (2): 251-265.

Lyons, K. (2000) 'Situated Knowledges, Science and Gender: A Sociology of Organic Agriculture in Australia and New Zealand'. PhD dissertation, Central Queensland University.

Lyons, K. (2001) 'From Sandals to Suits: Green Consumers and the Institutionalisation of Organic Agriculture', in S. Lockie and B. Pritchard (eds) Consuming Foods, Sustaining Environments, pp. 82-94. Brisbane: Academic Press.

Lyons, K. and G. Lawrence (2001) 'Institutionalisation and Resistance: Organic Agriculture in Australia and New Zealand', in H. Tovey and M. Blanc (eds) Food, Nature and Society, pp. 67-88. Aldershot: Ashgate.

Madden, B., G. Hayes and K. Duggan (2000) National Investment in Rural Landscapes: An Investment Scenario for NFF and ACF with the Assistance of LWRRDC. Australian Conservation Foundation and National Farmers' Federation.

Ministry for the Environment (1997) The State of New Zealand's Environment. Wellington: Ministry for the Environment and GP Publications.

Mues, C., L. Chapman and R. Van Hilst (1998) Landcare: Promoting Improved Land Management Practices on Australian Farms. Canberra: Australian Bureau of Agricultural and Resource Economics.

Monk, A. (1998) 'The Australian Organic Basket and the Global Supermarket', in D. Burch, G. Lawrence, R. Rickson and J. Goss (eds) Australasian Food and Farming 
in a Globalised Economy: Recent Developments and Future Prospects, pp. 69-82. Melbourne: Monash Publications in Geography No. 50.

Organic Producers Exporters Group (OPEG) (2000) OPEG Member Survey - 1999-2000. http://www.organicsnewzealand.org.nz/documents/survey2000.

Paehlke, R. (1999) 'Towards Defining, Measuring and Achieving Sustainability: Tools and Strategies for Environmental Evaluation', in E. Becker and T. Jahn (eds) Sustainability and the Social Sciences, pp. 245-263. Paris: UNESCO.

Pugliese, P. (2001) 'Organic Production and Sustainable Development: a Multifaceted and

Promising Convergence', Sociologia Ruralis 41 (1): 112-130.

Reeve, I (2001) 'Property Rights and Natural Resource Management: Tiptoeing Round the

Slumbering Dragon', in S. Lockie and L. Bourke (eds) Rurality Bites. The Social and Environmental Transformation of Rural Australia, pp. 257-269. NSW: Pluto Press.

Saunders, C., J. Manhire, C. Campbell and J. Fairweather (1997) Organic Farming in New Zealand: An Evaluation of the Current and Future Prospects Including an Assessment of Research Needs. MAF Policy Technical Paper. Canterbury: Department of Economics and Marketing, Lincoln University.

Sainsbury (2000) Environment Report 2000: Working Towards a Better Environment. London: J. Sainsbury plc.

Welford, R. (1997), Hijacking Environmentalism: Corporate Responses to Sustainable Development. London: Earthscan.

\section{Contents}

\section{Introduction}

2. Greening Agriculture and Food in Australia and New Zealand

3. Corporate Capital and Greening

4. The Entry of Corporate Capital to Organic Agriculture

\subsection{Uncle Tobys}

\subsection{Heinz Wattie}




\section{Constructing 'Organics': Food Products and Corporate Identity \\ 6. Retail Sector and Greening \\ 7. First and Second Phase Greening \\ 8. Conclusion}

\section{Authors}

Kristen Lyons lectures in Science, Technology and Society at Griffith University in Australia. Her current research interests include the sociology of organic agriculture, international trade and regulation of organic food, community supported agriculture and local food networks. She has recently published her research in these areas in Sociologia Ruralis, Rural Sociology, The International Journal of Sociology of Food and Agriculture and Agriculture and Human Values.

David Burch is a Professor in the School of Science, Griffith University, Brisbane, Australia, and Director of the Science Policy Research Centre. He is a political scientist currently teaching and researching in the areas of science and technology studies, with a particular interest in agriculture and social change in Australia and Southeast Asia, and is the convenor of the Agri-food Research Network. He is a co-editor of Globalisation and Agri-Food Restructuring: Perspectives from the Australasia Region, (Avebury, 1996), Restructuring Global and Regional Agricultures: Transformations in Australasian Agrifood Economies and Spaces (Avebury, 1999), and a special edition of Rural Sociology entitled Antipodean Visions (June 1999). He is also a co-editor of the International Journal of the Sociology of Agriculture and Food, and a co-author of Science, Technology and Society: An Introduction (Cambridge University Press, 1998).

Geoffrey Lawrence is Professor of Sociology and Head, School of Social Science at The University of Queensland. He has written widely in the areas of rural social change, regional restructuring and the sociology of agriculture and the environment. Among his recent co-authored/co-edited books are: Restructuring Global and Regional Agricultures (Ashgate, 1999); Environment, Society and Natural Resource Management (Edward Elgar, 2001); A Future for Regional Australia (Cambridge, 2001); Altered Genes II 
(Scribe, 2001); and, Globalization, Localization and Sustainable Livelihoods (Ashgate, 2002).

Stewart Lockie is Director of the Centre for Social Science Research at Central Queensland University. His current research addresses food production and consumption, natural resource management in agriculture, social impact assessment and coastal zone management. He is co-editor of Critical Landcare (1997), Rurality Bites: The Social and Environmental Transformation of Rural Australia (2001), Consuming Foods, Sustaining Environments (2000) and Environment, Society and Natural Resource Management: Theoretical Perspectives From Australasia and the Americas (2001). 